Running head: THE ROLE OF HIGH POTENTIALS

Final article:

Lindgreen, A., Swaen, V., Harness, D., and Hoffmann, M. (2012), "The role of 'high potentials' in integrating and implementing corporate social responsibility", Journal of Business Ethics, Vol. 99, No. 1, pp. 73-91. (ISSN 0167-4544)

For full article, please contact LindgreenA@ cardiff.ac.uk

\title{
THE ROLE OF 'HIGH POTENTIALS' IN INTEGRATING AND IMPLEMENTING CORPORATE SOCIAL RESPONSIBILITY
}

\author{
Adam Lindgreen, University of Cardiff \& BEM Bordeaux Management School ${ }^{1}$ \\ Valérie Swaen, Université catholique de Louvain \\ David Harness, Hull University Business School \\ Marieke Hoffmann, Eindhoven University of Technology
}

\footnotetext{
${ }^{1}$ For all correspondence: Dr. Adam Lindgreen, Professor in Marketing at the University of Cardiff \& Research fellow at BEM Bordeaux Management School. Correspondence address: Professor Adam Lindgreen, Cardiff Business School, the University of Cardiff, Aberconway Building, Colum Drive, Cardiff CF10 3EU, the U.K. Email: LindgreenA@cardiff.ac.uk.
} 
Running head: THE ROLE OF HIGH POTENTIALS

\title{
THE ROLE OF 'HIGH POTENTIALS' IN INTEGRATING AND IMPLEMENTING CORPORATE SOCIAL RESPONSIBILITY
}

\begin{abstract}
The Samenleving and Bedrijf (S\&B) network of Dutch organizations seeks to embed corporate social responsibility (CSR) within business practices but faces challenges with regard to how to do so across various organizational practices, processes, and policies. The integration of CSR demands cultural change driven by senior management and other change agents, who push CSR principles throughout the organization. This study examines the change processes that $\mathrm{S} \& \mathrm{~B}$ member organizations have initiated, with a particular focus on the role of high potentials - those persons who have been selected for the fast track into senior management. Interviews with nine S\&B organizations document their levels of CSR integration and implementation, the role of senior managers, and the effects of high potentials' competencies on the realignment process. High potentials have the ability and opportunity to act as CSR change agents, but organizations' expectations of their purposes as future senior managers prevented them from doing so. In the existing organizational cultures, leadership focused on economic success, and the CSR implementation process had just initiated. Therefore, a measure of CSR embeddedness might refer to the performance measurement and expectations of high potentials as potential CSR change agents.
\end{abstract}

KEYWORDS. Corporate social responsibility; high potentials; change agents; integration; implementation; case study. 


\section{Running head: THE ROLE OF HIGH POTENTIALS}

\section{Introduction}

Becoming oriented toward corporate social responsibility (CSR) requires an organization to alter its business model to accommodate the principles of CSR. These underpinning principles, as summarized by Carroll (1979), are balance between profit generation (economic) and good citizenship (social), without harm to the environment (environmental) - that is, the triple bottom line framework. Maintaining the economic well-being of the organization is an essential condition to ensure it can meet social and environmental requirements (Elkington, 1997; SER, 2000). The responsibilities framework (Carroll, 1979; Maignan, 1997) adds two important constructs: First, society believes an organization is responsible for its actions, so it must gain its economic objectives without causing to harm to social and environmental factors. Second, organizations have discretionary responsibility, such that for issues on which society takes no clear position, they should be responsible for more than the bare minimum of regulatory requirements. Failure to do so, as the example of Enron shows, represents unethical behavior (Carroll, 1979). A person's or organization's CSR-related values in turn determine interpretations of discretionary responsibility, which may be broadened by consideration of various stakeholders, such as employees, owners, and external parties, that influence and are influenced by the actions of an organization (Vos, 2003). Because economic criteria have historically dominated business practices and success definitions, the adoption of CSR and its distinct definitions of business success likely require cultural change in the organization (Doppelt, 2003; Dunphy et al., 2003; Placet et al., 2005).

The defining principles of CSR as an umbrella concept generally seem well understood and articulated (e.g., Garriga and Melé, 2004; Joyner and Payne, 2002; Lindgreen et al., 2009; Vos, 2003). Less well understood is how CSR might become embedded within an organization and 


\section{Running head: THE ROLE OF HIGH POTENTIALS}

thereby determine business activities, which is the challenge that currently faces Samenleving and Bedrijf (S\&B). This network of Dutch organizations is aware of CSR but unsure of how to implement it to achieve full integration. Organizations can achieve integration by ensuring their policies, practices, and processes are congruent with CSR principles, which in turn may provide two distinct and linked benefits. First, it mitigates the charge that organizational CSR is nothing more than marketing communication in response to shifting governmental and social expectations (Pedersen and Neergaard, 2008) or "window dressing" (Meyer and Rowan, 1977). Second, by embedding CSR into policies and everyday business practices, the firm reduces the potential that CSR comes decoupled from decision making when the organization confronts economic challenges (Weaver et al., 1999).

Both of these outcomes rely on organizational cultural change (Doppelt, 2003; Dunphy et al., 2003), which can be achieved through positive senior management leadership (Lyon, 2004; Maon et al., 2009; Werre, 2003) that supports change and pushes CSR principles throughout the organization (Cramer et al., 2004). Current managers and employees with high potential to become senior managers in the future (hereafter, high potentials) likely play significant roles in ensuring that CSR becomes the dominant business agenda that is integrated into all policies, practices, and processes. According to Randel (2002, p. 70), "although managerial activity must fall within the parameters of organizational role, managers have many opportunities to make decisions (discretionary responsibility) and take actions based on their own convictions that supports socially responsible practice."

Yet no existing research explores the link between high potentials and CSR implementation and integration. Therefore, we consider what CSR integration is, the stages involved in CSR implementation, and the role that managers, and specifically high potentials, may play. To do so, 


\section{Running head: THE ROLE OF HIGH POTENTIALS}

we first conceptualize a theoretical framework based on a literature review of research related to CSR integration, implementation, and managers and future managers' roles. We also report the findings of an empirical study in which we qualitatively explore how S\&B members have embedded CSR and the extent to which high potentials, as critical change agents, support the process. Finally, we identify the study's theoretical and managerial contributions, address some limitations, and suggest avenues for further research.

\section{Theoretical Background}

Integration represents the desired end stage of a set of activities an organization undertakes to orient toward CSR, which requires culture change. Culture reflects the underlying assumptions about the way work should be performed and what constitutes acceptable or unacceptable business practices (Atkinson, 1990). We might identify CSR-generated cultural change by, for example, employee rewards and recognition that are linked to CSR adoption and learning (Lyon, 2004; Werre, 2003). Ethics research suggests that integration also involves dedicated training about and formalized auditing of activities to ensure their compliance with CSR ideals (Maon et al., 2010; Paine, 1994; Weaver et al., 1999).

Without such integration and reinforcement, CSR likely remains nothing more than a public relations activity, such that the ties that bind CSR to the organization's commercial activities eventually break (Weaver et al., 1999). Bateson et al. (2006) call this state of affairs moral hypocrisy, because CSR is simply a marketing activity that becomes "shallow and ultimately a useless concept" (Maak, 2008, p. 356).

This description prompts two questions: First, how does an organization measure the extent to which it has achieved CSR integration? Second, how does an organization deepen the level of 


\section{Running head: THE ROLE OF HIGH POTENTIALS}

this integration? Outcome measures, such as employee rewards linked to CSR adoption, might address the first question at least partially, but they cannot demonstrate full adoption of a value system. The second question thus seems easier to answer, by considering prior studies about CSR integration and implementation.

\section{CSR integration}

In a final CSR integration stage, all of an organization's activities are determined by its compliance with CSR principles. The extent to which organizations achieve this goal determines their level of CSR integration (see Table 1). Two frameworks define different levels of CSR integration. First, Dunphy et al. (2003) suggest that an organization rejects CSR because it perceives the concept as burdensome; engagement then results from regulatory pressure, which ultimately leads to the acceptance of its potential for providing economic benefits.

Second, another framework posits that individuals, organizations, and societies have consistent sets of values, beliefs, and corresponding behaviors that form their value systems. These systems evolve in a fixed order: from survival to security, energy and power, order, and success, and finally to community, synergy, and holistic life systems. Each new value system includes and goes beyond the previous ones, forming a natural hierarchy. For example, organizations initially need to establish cash flow, which drives all their decisions. As they gain success, they can focus on fulfilling their moral and environmental obligations. Van Marrewijk and Werre's (2003) framework therefore assumes that CSR integration reflects the extent to which managers and employees align their values with the overall principles of sustainability and allow it to influence the way they conduct business. 


\section{Running head: THE ROLE OF HIGH POTENTIALS}

The differences in the driving forces between these two frameworks reflect the debate about whether CSR is appropriate because it provides instrumental benefits, because it supports wealth maximization for shareholders, or because it provides moral benefits and enables the organization to do the right thing (Waldman and Sigel, 2008). However, both frameworks arrive at the same place: CSR becomes the "glue" that binds the organization's activities

\section{\{Take in Table 1$\}$}

Furthermore, both frameworks suggest integration is a sequential process; we also note this process may lack sharply defined boundaries between stages and reveal haphazard progressions. For example, the internally determined human resource policies of a single company could be in a proactive or caring phase, but its environmental policies, which require negotiation and agreement with external parties, simultaneously could be stuck in the efficiency- or profit-driven phases. The stages in each framework thus highlight the different levels of organizational cultural change required to become fully integrated with CSR, though they cannot reveal how such implementation may be achieved.

\section{CSR implementation}

The frameworks that outline CSR implementation generally indicate that it is an organizational change process (Doppelt 2003; Were, 2003), though little agreement exists about how many or which stages are involved. For example, Werre (2003) suggests four holistic stages: raising top management awareness, formulating a CSR vision and core corporate values, changing organizational behavior, and anchoring change. Doppelt's (2003) "wheel of change" instead comprises seven stages: alter the goals of the system, restructure the rules of engagement, shift the flows of information, correct the feedback loop, adjust parameters, change the dominant 


\section{Running head: THE ROLE OF HIGH POTENTIALS}

mind set, and rearrange the parts of the system. The circular processes reflect the different time scales required to attain different levels of integration, such that some stages must be repeated to move forward.

Jonker and De Witte (2006) add that CSR becomes organizationally embedded only when it results in total added value for the organization. Their integrated CSR management framework focuses on shaping the business proposition, defined as the organization's mission, vision, and business strategy. This proposition then determines the nature of the organization's identity, its systems, and the levels of accountability and transactivity, such that each becomes CSR-oriented and facilitates integration.

Cramer et al.'s $(2004,2006)$ approach, which they call "sense making of CSR," assumes that change agents interpret what CSR means within their specific operating context. Change agents implement CSR by translating their own views and intentions into language and actions that push the organization to change its values (Cramer et al., 2004). The CSR implementation of each organization therefore is unique, determined by the views of its change agents and their personality, functions, and circles of influence (Cramer et al., 2004).

Porter and Kramer's (2006) consider business and society mutually dependent; investing in facilities to improve workforce health results in productivity gains, for example. This instrumental focus requires the organization to assess the fit between its commercial interests and the societal needs that may affect its ability to succeed.

Stakeholder theory provides a basis for understanding the CSR implementation process. For example, Maignan et al. (2005) emphasize the need to consider stakeholders when defining short-term outcomes and shaping the strategic focus, because this consideration leads to shared ownership and an accepted understanding of where the organization is heading. In this sense, 


\section{Running head: THE ROLE OF HIGH POTENTIALS}

CSR implementation is a negotiated activity, a theme further developed by Castka et al. (2004), who point out that organizations build on what exists and therefore are limited in their ability to introduce wholesale and complete change, so it must also be an incremental process.

Although these frameworks offer slightly different views about how to implement CSR to achieve integration, they also entail some common elements, as we summarize in Table 2. An organization might not pass through every stage, and the stages may progress sequentially or simultaneously, as well as repeat. Therefore, the implementation process appears circular rather than linear. The link across the stages is individual responsibility to drive change (Cramer et al., 2004).

\{Take in table 2$\}$

\section{High potentials}

An organization works toward CSR integration by undertaking various activities, such that its mission, vision, and strategic thrust cascade into its policies, practices, and processes. All stakeholders have a role to play in setting the CSR agenda, but at the start, it needs considerable buy-in from senior mangers (Thomas and Simerly, 1994). Senior management is responsible for creating "a vision for the future which is aligned to the demands from the environment and communicat[ing] this vision in a manner that inspires people to act in accordance with the vision" (Werre, 2003, p. 248). If managers fail to demonstrate this strong moral responsibility, according to Hemmingway (2005), it is doubtful whether greater CSR integration is possible. Maak (2007, p. 330) recognizes that "we still have little knowledge about responsible leadership and even less about how to develop responsibility in leaders to prepare them for the challenges of a global and interconnected stakeholder society." In turn, responsibility for the development of 


\section{Running head: THE ROLE OF HIGH POTENTIALS}

CSR within the organization and its usage falls onto managers, as well as those being groomed to become senior managers in the future. Yet research leaves unknown the role that high potentials, as future managers, may play and how the organization can support them.

High potentials, as a group of employees, possess certain attributes that make them attractive as CSR change agents. Change agents employ tactics such as persuasion and vigilance to champion an issue and drive change (Beatty and Gordon, 1991). They possess strong personal and business competencies, such as self-confidence and awareness, ambition, clear objectives, dedication and motivation, communication and social skills, leadership, analytic and problemsolving skills, teamwork and team building, creativity and flexibility, the ability to organize and manage, independence and autonomy, and prioritization of improvement and innovation. These competencies might be inherent personal characteristics, such as the willingness to push themselves and others (Gritzmacher, 1989; Jones and Spooner, 2006), or gained through management development (Pepermans et al., 2002) or supportive communications (Rausch et al., 2001). They also confirm that high potentials can perform as senior managers (Altman, 1997; Burke, 1997).

But to perform as CSR change agents, high potentials likely need additional competencies. Personal and social-based competencies determine people's ethical and moral principles (Kellerman, 2006). In particular, personal competencies evolve from self-awareness, motivation, sincerity, passion, and conviction for CSR, so they enable the creative application of resources to overcome implementation barriers. Social competencies instead derive from social awareness, willingness to listen, recognition of different perspectives, and openness to dilemmas. Therefore, high potentials with strong social competencies likely understand the relevance of their relationships with different stakeholders and how to achieve goals through communication. 


\section{Running head: THE ROLE OF HIGH POTENTIALS}

Overall, sustainable leadership results from the interaction of leadership constructs, personal moral standards, and the abilities to relate to different groups, align various values into a common vision, and exhibit empathy for others (Maak and Pless, 2006).

In Table 3, we compare sustainable versus regular core competencies and find considerable overlap. That is, organizations already recruit employees who exhibit some of the qualities required for sustainable leadership. The differences relate to the person's orientation toward ethical and moral values, the desire to achieve success by working with others, and the willingness to continue learning.

$\{$ Take in table 3$\}$

Finally, we note that prior literature suggests that CSR integration occurs through organizational cultural change, comprising various levels of integration that serve as markers and different types of activities required to implement CSR. The change process requires that the persons who take ownership of CSR principles must encourage them in daily work practices and thus ultimately change the organization's value system. This process cannot be instantaneous; instead, it must be time-consuming and continuous and require the support of both current and future senior managers. Therefore, we adjust our research questions: First, can organizations, as part of their overall CSR implementation strategies, use high potentials as change agents? Second, what competencies do high potentials need to become CSR change agents? To answer the first question, we need a holistic understanding of the extent to which organization members have implemented CSR; to answer the second, we require an understanding of what organizations expect of high potentials.

\section{Methodology}




\section{Running head: THE ROLE OF HIGH POTENTIALS}

We choose a qualitative approach for this study, because we investigate complex phenomena and need to take many variables into account (Eisenhardt, 1989; Matthyssens and Vandenbempt, 2003; Yin, 1994). Specifically, we use a case study with secondary data and multiple interviews to develop rich insights and provide a basis for transferring our findings to other contextual settings (Eisenhardt, 1989; Lindgreen, 2008). As the established body in the Netherlands for promoting CSR for business organizations, S\&B offers a good subject. Its 28 members include highly respected and leading national and multinational organizations.

Because our goal for this exploratory research was to develop an understanding of the CSRrelated competencies required for high potentials, as well as how management might help them add value to CSR implementation, we focus the data collection effort on identifying the sampled organizations' CSR adoption stage. The evaluations of their mission statements, strategies, values, and principles, as well as the CSR strategies and activities they had in place, provides case-specific contexts for examining the link between the CSR implementation stage and high potentials' involvement with regard to managerial development activities and desired core competencies. For the interviews, we identified four main topic areas, derived from our literature review and secondary organizational data: organization description; mission, strategy, and values (or principles); CSR strategy and activities; and the nature of high potentials' competences.

\section{Case description}




\section{Running head: THE ROLE OF HIGH POTENTIALS}

All the participating organizations are members of the S\&B network, which means they are committed to developing CSR practices. ${ }^{2}$ However, each member is likely to represent a different level of adoption. To ensure our results apply to organizations outside the S\&B network as well, we ensured that the sample represents six different industries. We interviewed employees of two firms from the accountancy and consultancy, information and communication technology, and finance industries, and we interviewed member from the telecommunications, electronics, and mail and logistics sectors. Each of these targeted organizations actively implements CSR across the entire company; other members of S\&B have yet to move from the awareness or creation stage to CSR implementation, so they probably have not amended their recruitment or training policies to reflect a stronger CSR orientation.

\section{Data collection and analysis}

To build each case, we collected data with various methods. First, the case study organizations provided written documentation, including annual reports, corporate responsibility reporting documents, and information related to the recruitment and training of new employees and high potentials. In addition, we evaluated the organizations' Web sites and pertinent academic papers. These data offer comprehensive insights into the CSR practices and recruitment and management development activities of the sampled organizations.

Second, we conducted interviews with 14 persons responsible for either the recruitment and development of high potentials or the implementation of CSR. Each semi-structured interview lasted between 45 and 60 minutes. Although we had hoped to interview both the CSR and the

\footnotetext{
${ }^{2}$ The S\&B networks main goals are to embed CSR into participating organizations' business processes; actively contribute to Dutch social issues; inspire employees in member organizations to adopt CSR; and influence the Dutch CSR agenda.
} 


\section{Running head: THE ROLE OF HIGH POTENTIALS}

recruitment managers in each organization, we could not do so for two firms (either because the same person could address both sets of questions or because a manager was unavailable during the time of the study). All interviews continued until they reached saturation, that is, no extra questions yielded additional insights (Strauss and Corbin, 1998). Although the interviews provided most of the necessary information, we gathered any missing information from other data resources, such as the organizations' Web sites. The interviews were recorded and transcribed, then translated into English. The transcriptions created 43 pages of text (Arial, 11point, single spaced). To analyze the transcriptions, we first eliminated irrelevant data, then divided the remaining data into the four main categories: mission, strategy, and values (or principles); corporate social responsibility; high potentials as CSR change agents; and high potentials' CSR competencies.

These multiple methods for collecting data enhance the robustness of the study's findings, help compensate for the weaknesses of any one data collection method, improve the quality of the final interpretation, and help ensure triangulation (Beverland and Lindgreen, 2010; Jick, 1979; Strauss and Corbin, 1998; Yin, 1994). Because the unit of analysis is each case organization, we combine the information from each set of interviews and the secondary sources into a final case manuscript for each organization. Throughout the study, we also adopted precautions to improve the research quality. First, in preliminary research, we identified the most appropriate members of S\&B to ensure a broad range of organization types and levels of CSR commitment. Second, the three researchers involved in this study each provided independent interpretations of the findings. Third, we conducted multiple interviews and gave interviewees the opportunity to provide feedback on the initial findings. These tactics also reinforce the reliability of our findings. Furthermore, whereas colleagues performed the independent coding of 


\section{Running head: THE ROLE OF HIGH POTENTIALS}

the transcripts, all the interviews were conducted by the same interviewer, which reduces the potential for bias (Lincoln and Guba, 1985; Strauss and Corbin, 1998).

\section{Findings}

The organizational data sources, such as Web sites, company reports, and the interviews, revealed how the organizations had changed their activities to support their CSR implementation; the extent to which they had achieved their CSR integration; whether high potentials were involved in the CSR implementation; and the opportunities for high potentials to become involved in the CSR implementation.

Mission, strategy, and values

A CSR orientation is likely to appear in an organization's mission statement, with further elaborations in its business strategy and corporate values. Of the nine sampled organizations, three mission statements made direct references to CSR, such as enriching customer lives, ensuring employees consider social issues when performing their duties, and taking responsibility for the organization's impact on the world. The other six organizations highlight CSR in their strategy statements and employee value policies. As part of strategy, their CSR appears in phrases such as teamwork, developing people, and excelling in business collaboration.

To translate a mission into operational activities requires that CSR underpins the values and principles that define business conduct and the treatment of employees. All nine organizations listed certain values and principles, and though they vary in number, at least half of them centered on CSR. This finding indicates that organizations have begun the process of cultural change to achieve their CSR orientation. The most common CSR themes include a focus on 


\section{Running head: THE ROLE OF HIGH POTENTIALS}

employees and teamwork, leading by example, working with partners that share similar CSR views, being responsible corporate citizens, taking personal responsibility for their actions, respecting human rights and the environment, being accountable, being open, and working in a context of mutual respect.

\section{Corporate social responsibility}

As an inherent feature of the CSR framework, the organization must align its strategic thrust with the principles of CSR, with the support and perhaps impetus of senior managers. All organizations had the support of their senior manager to promote CSR, though that support depended on the managers' personal views, as the following quotes demonstrate:

"They [i.e., the board] have a personal interest. They realize society is changing, customers change, and they want to adapt to that." (CSR Manager, Bank 1)

"We noticed that when we took proposals to the board, it was difficult to discuss with them why CSR is important for the company. That is what surprised me. We can readily make a decision on a business issue, we can invest, we can sell and buy, but deciding on a theme in CSR, that is something personal." (Board member, Accountancy Company 1)

"I personally think that looking at the change in our environment, accountants and consultants are covered under rules and administrative burdens to do their business. A second pillar has to support the business, that is CSR. The company and its employees have to take the responsibility for what is happening in their surroundings." (Board Member, Accountancy Company 2)

Therefore, the desire to keep the organization aligned with the CSR views of wider society drives their CSR adoption, but the individual values of the senior mangers shape what that adoption means for the organization.

Further evidence of senior management support emerges with regard to how the organization publicizes its CSR activities. All organizations reported CSR activities in their shareholder reports or more focused publications, such as a sustainability report. This publication seems to 


\section{Running head: THE ROLE OF HIGH POTENTIALS}

encourage the elaboration of CSR into principles and policies. For example, seven organizations expressed specific CSR principles, and two embedded them into their business practices. Four organizations undertook CSR initiatives aimed at developing a specific staff group or the whole organization - for example, creating teams of young employees tasked with implementing CSR, rewarding staff who worked on community projects, or partnering with UN initiatives to support children's education in developing countries.

Several factors also appear to determine the speed of CSR implementation. First, with one exception, all the organizations were in good economic health, which enabled them to devote resources to CSR. The one exception was focused on securing its financial well-being; it also regarded CSR as an important but a lesser priority. Second, the duration of the organizations' CSR involvement largely determined their stage. The majority of firms were still developing their strategy, though two considered themselves on the road to implementation. Third, selecting a CSR strategy that appealed universally to employees was challenging. Fourth, both organizational size and the extent to which individual members valued CSR also influenced implementation, as the following quotes show:

"Employees were enthusiastic to do something. The support from the board could be better. It seems like it is only a communication issue right now. It should be a more important issue within [the company], it should be implemented in the whole organization, but [the company] is not that far. Right now, [the company] is searching which way they should go with CSR and the implementation." (Corporate Communications Manager, Electronics Company)

"Awareness is a step-by-step process that takes time, and we are not done yet. I think that everybody at Bank 1 knows that we are involved in CSR, that about $25 \%$ of the employees understand what our choices are in CSR, but a large group does not yet know. People feel a certain involvement with the issues in society that they see in the media and think what it means for them in work life." (CSR Manager, Bank 1) 


\section{Running head: THE ROLE OF HIGH POTENTIALS}

The extent to which employees support CSR thus is critical to CSR implementation. In this sense, implementation pertains to the values employees hold and how those values align with the values of the organization.

\section{High potentials as change agents for CSR implementation}

Change agents use their views and values to influence the nature of CSR within their organization. Organizations might believe that high potentials can serve this role; our results reveal that because of their youth, they seem to reflect current societal norms, such that they were expected to have knowledge and understanding of CSR. That is:

"They live in a different period. They are confronted with all kinds of issues in the world and they are concerned about that. As a leader you are forced to think about these issues and do something about it." (Manager Environment and Sustainability, Accountancy 1)

"They are the people of the future. What you see is that it is an important strategic issue for our board that young people have CSR in their head and heart." (CSR Manager, Accountancy 2)

The society from which the organizations recruit their employees faces the constant challenges of, for example, environmental issues and social concerns. Unlike current senior managers, whose business philosophies likely were forged during a different period, young high potentials, simply by virtue of their membership in modern society, are perceived to have relatively higher awareness of CSR.

The organizations also believed that new employees, especially young ones, should be exposed to CSR early in their careers. Four organizations used training or mentoring to communicate their values and principles. One organization even differentiated between high potentials and normal staff with regard to the level of CSR exposure they received when they joined the organization. However, most firms did not identify their high potentials until after they 


\section{Running head: THE ROLE OF HIGH POTENTIALS}

had worked for the firm for a period of time, and many believed new employees needed time to adjust to working in a new organization. Therefore,

"For young starters it is good that they are confronted with CSR and take it into account in their ambition; that is clear. In the long term, they can translate that to their employees, but in the first year they cannot do that. Then they are searching for their own role within the organization instead of putting sustainability on the agenda. I see this as a long-term role for them. I also think it should not be a topic for a select group, but that it should be embedded across the organization." (Manager CSR, Bank 2)

"It is important to involve them from the beginning. But it is important that everybody at [the company] knows CSR. I do not think they are the most important, but they are one of the important parties.” (Corporate Communications Manager, Electronics Company)

Even when the high potentials did not serve as CSR change agents though, they were included

in activities designed to increase awareness and help shape CSR policy, such as spending a working week on a CSR initiative or being part of a cross-functional team involved in a zero assessment exercise:

"In the essential projects I include young people; they get prominent attention when we promote it externally or internally. Besides that I include important people on a higher level to create a win-win." (CSR Manager, Accountancy 2)

"Depending on the position they reach, they can have a lot of influence. So they are important for the future. A leader is important for a company and what they do. If a leader thinks CSR is an important issue than he will use that in his company. So if a high potential becomes a member of the executive board of a company he can have a lot of influence." (Manager for Environment and Sustainability, Telecommunications)

The leadership progression cycle thus brings high potentials in contact with a wide range of employees from different business functional areas. In turn, they can identify and attempt to understand the values of other employees, as well as the challenges associated with aligning their views with the organizations' CSR objectives.

\section{High potentials' CSR-oriented competencies}




\section{Running head: THE ROLE OF HIGH POTENTIALS}

Recurrent throughout the interviews was a belief that individual members have personal ownership of CSR as a sort of inherent characteristic, though the lack of a CSR orientation was not necessarily as a barrier to recruitment:

"If people have no affinity with CSR they will not be rejected right away. There are many people who have not thought about the issue and that are just confronted with it when they start at [the company]. Then they might find it very interesting." (Recruitment manager, Logistics company)

"We do not want to take the risk of reputation damage, so we are aware of what we do and with whom, but the main focus is still profit and keeping our stakeholders satisfied. So we will really steer on cost reduction, also in the projects the trainees do." (Young Talent Manager, Bank 2)

Instead, the imperative for all sampled organizations was that they recruited persons they could develop into managers who would be capable of leading the organization to success in terms of its economic objectives. All S\&B members are involved in CSR implementation, so we had expected CSR competencies would be criteria for hiring high potentials. As we show in Table 4 though, only four CSR competencies receive confirmation (from three or more organizations) as important. Integrity, compliance, trust, and honesty is the most relevant, followed by responsibility in relationships and teamwork, which is not surprising considering the nature of these competencies. However, the low level of acceptance of the other competencies suggests that organizations have yet to fully understand or define them in relation to their own business needs. It also offers evidence that organizations do not link their CSR implementation to high potentials, whether by recruiting employees that already possess such skills sets or by developing them through management training.

$\{$ Take in table 4$\}$

When we asked if the organizations' competency requirements had changed to take CSR into consideration, two companies noted their active efforts: 
"The competence profile changed based on new insights, also because of new board members internationally. A new person has new ideas and visions. That is based on a changing world. [The company] is a product as well as a project company. We observed that products alone is not sufficient anymore, you need to do more to stay ahead of your competitors. That means that image, changing fast and flexibility of people becomes a more important theme. Then you notice that next to knowledge and experience the behavioral component becomes more important.... That is influenced by the outside world and new insights. Based on that, the competence profile changed. CSR has had an influence on the change of the competences. It is, of course, a win-win situation. We do not do CSR for charity. What we want to search for consciously is where the profit is for us and for the end user." (Manager Development Academy, Electronics)

"I think high potentials can play a role in CSR implementation, but I do not consider them crucial for the success of current social involvement programs since these are meant for all employees. Knowledge and skills of high potentials could be used in the broader discussion, but the question is will it deliver growth for us. Especially because it has less attention among our type of company and also is seen as less relevant by the outside world." (Director Marketing and Communications Director, ICT Products and Services company 1)

Whereas these two organizations had developed new competency criteria that affected their selection and development of high potentials, the other organizations were less certain. Three stated that they did not seek to recruit or train high potentials in CSR, though they did expect them to exhibit the values the organization prioritized. None of the organizations stated that they recruited on the basis of prospective employees' CSR beliefs. Instead, they asserted that high potentials had to perform well for the business, which meant that their development had to remain broad-based.

\section{Discussion}

To understand how high potentials might embed CSR into an organization, we first assessed the level of integration of our case organizations. Although economic requirements remain dominant, all our organizations had reached at least a strategic or synergistic CSR phase, such that CSR had become an important part of their overall business strategy. None had reached the 
Running head: THE ROLE OF HIGH POTENTIALS

point that CSR was fully embedded though; the level of integration achieved by each organization varied according to the length of time it had been involved in CSR and the existence of other competing (economic) priorities. In contrast with the similar outcomes that result from Dunphy et al.'s (2005) and Van Marrewijk and Werre's (2003) frameworks, we instead find two unique drivers of organizations' efforts: instrumental and morality. Both driving forces are exemplified in the actions undertaken by the S\&B, which seems to support Waldman and Sigel's (2008) claim that CSR integration begins with economic benefits, then evolves with the shift in values. The balance between the two drivers appears unique to each organization, though S\&B can appreciate at least that the sampled organizations have moved beyond awareness generation.

The findings also suggest a comprehensive implementation framework (Table 5). Organizations move through each phase according to their own needs. For example, in the case study organizations, we find evidence that they had started the CSR process by aligning their mission, vision, and values with CSR, which represents a significant step (Jonker and De Witte, 2006). The work to realign their corporate cultures remained an ongoing and considerable challenge. As Porter and Kramer (2006), Maignan et al. (2005), and Castka et al. (2004) note, CSR implementation is a gradual activity based on negotiated outcomes with stakeholders in an attempt to gain collective support for the desired change.

$\{$ Take in table 5$\}$

As a measure of cultural change, we have considered the recruitment of high potentials because of their CSR-oriented competencies. None of our focal organizations did so, nor do we find evidence that they focused on developing such competencies among existing employees. These skills may develop indirectly when the organizations' principles and values focus on CSR. Furthermore, the organizations could define sustainable leadership competencies that overlap 


\section{Running head: THE ROLE OF HIGH POTENTIALS}

with regular competencies. For example, trust and integrity, creativity, relationship management and teamwork, coaching, communication, and facilitating change and social awareness are both regular and sustainable leadership competencies. The acquisition of other competencies and the realignment of existing ones to support CSR implementation again represents an incremental process and provides a strong foundation, which may reduce resistance to change and speed the CSR implementation.

However, the majority of the sample appeared reactive with regard to the adoption of CSR principles by high potentials. High potentials received the same exposure to CSR principles as did other employees, with the consistent objective of ensuring the employees understood the organizations' CSR philosophies, strategy, mission, values, and policies. In addition, according to these organizations, the purpose of high potentials is to become future leaders of the business and achieve economic success. Thus, even though high potentials have the leadership skills needed to support CSR implementation, they were not used as change agents, because the conditions in the organization did not enable them to serve this function. Although organizations do not use high potentials in this role currently, they generally believe they will in the future.

\section{Management implications}

A key driver of CSR integration is the notion that it can become deeply embedded in an organization's policies, practices, and processes. Thus, the organization can prove to its constituent stakeholders that its adoption of CSR is a serious endeavor, not a cynical marketing communication activity. But defining a CSR strategy and aligning the organization's mission, vision, and values may constitute the easy part. The much harder part is converting these concepts into actual practices, policies, and processes, even when the focus of the activities is 


\section{Running head: THE ROLE OF HIGH POTENTIALS}

internal to the business. High potentials could play a significant role in CSR implementation and integration, but allowing them to do so also appears difficult, because ultimately, their purpose is to lead the business to economic success. Success still is defined as the imperative to create shareholder wealth; broadening the definition of high potentials' contribution to the organization therefore may be a critical goal of CSR integration activity.

Yet economic success cannot be ignored; it provides the resources that support social and environmental activities. To overcome the challenges posed by an economic imperative requires a strong link between the organization's CSR ambitions and the roles the high potentials undertake. Therefore, organizations must overcome a key barrier: CSR integration by its very nature may be ephemeral, because it reflects external views of what CSR is, as well as how the organization determines it, both of which are subject to change. Implementation frameworks consistently recognize that the process is iterative in nature and continuous. Therefore, critical markers may provide a good means to assess both the extent of change in the culture and the evolution of the organization as a whole. One clear marker would be whether high potentials take responsibility for CSR implementation and integration and whether this task is regarded as a positive goal, not a diversion from more important business activities.

\section{Limitations and further research directions}

As does most research, this study contains certain limitations that affect the interpretation of the results and suggest directions for further research. First, though the case study organizations can be considered representative of S\&B members, the study involves only Dutch businesses. Another investigation that considers these issues in other European countries or North America, where the legal requirements differ, could provide additional insights. Second, a longitudinal 


\section{Running head: THE ROLE OF HIGH POTENTIALS}

study may highlight more fully how CSR, as employees take ownership of it and integrate it into their business practices, affects the selection and development of high potentials, and thus their ability to become CSR change agents, which in turn would increase the speed of implementation and sustainable integration. Third, much of our discussion is based on the assumption that high potentials represent a young generation and therefore have strong CSR-based values. The extent to which this assumption is true, and the role that high potentials might want to play as CSR champions, demands careful evaluation. With such an understanding, organizations could determine how to recruit, develop, and ultimately use high potentials to achieve their CSR objectives. 


\section{Running head: THE ROLE OF HIGH POTENTIALS}

\section{APPENDIX}

\section{CASE 1: ABN AMRO}

International bank with 4,500 branches in 53 countries, employing 110,000, with assets of 999 billion Euros, focused on consumer and commercial clients and globally on select multinational corporations, financial institutions, and private clients.

\section{Mission, Strategy, and Values}

'To create maximum economic value for our shareholders through a constant relationship focus on the financial services needs of our chosen client segments and a strict adherence to our financial targets. We are operating in three principal customer segments, whereby the objective is to maximize the value of each of these businesses as well as the synergies between them. Excellence of service to our clients and leadership in our chosen markets are of paramount importance to our long-term success.' (ABN AMRO Corporate Website)

\section{Corporate Values}

Integrity: teamwork: respect: and professionalism, underpin businesses principles to guide and evaluate employees and define what the bank stands for: we are the heart of our organization: pursue excellence; aim to maximize long-term shareholder value; manage risk prudently and professionally; strive to provide excellent service; build our business on confidentiality; assess business partners on their standards; a responsible institution and a good corporate citizen; respect human rights and the environment; accountable for our actions and open about them. Collectively seen as essential to achieving mission and used to develop policies and procedures.

\section{Corporate Social Responsibility}

'To live our Corporate Values and Business Principles and to meet the needs of the organization and our stakeholders, thus seeking to protect, sustain and enhance human, natural and financial capital needed in the future.' To 'be committed to continuously improving the integration of sustainability into our working environment and business processes. Our aim is to play a proactive role in contributing to sustainability, within our spheres of influence. We are committed to accountability and transparency in our sustainability performance.' (ABN AMRO Sustainability Report 2006)

Fulfilling its values and principles enables it to meet organization and stakeholders needs to protect, sustain and improve human, natural, and financial capital and achieve sustainable growth. CSR strategy based on six principles: 1) Being accountable and transparent: 2) Protecting the assets: 3) Providing responsible financial services: 4) Being an employer of choice: 5) Supporting local communities: 6) Minimizing impact on the environment:

\section{Corporate Social Responsibility and High Potentials CSR implementation}

Stimulates all employees to consider and be involved in CSR; high potentials can spend one week of their working hours a year on volunteer work. High potentials are not tasked with CSR implementation.

\section{Competences}

High potentials' competencies relate to the key values of the company (integrity, teamwork, respect, and professionalism). Plus initiative, courage and risk taking, commercial drive, result focus and ambition, problem analysis and judgment. This competence profile is relatively constant but improved regularly. Trainees evaluated on key values and competences and aspects of CSR inherent in these, but specific CSR evaluation not undertaken. 


\section{Running head: THE ROLE OF HIGH POTENTIALS}

\section{CASE 2: ING BANK}

Leading global financial services company; interests in banking, insurance, and asset management services; employing 120,000 worldwide whose customers are individuals, families, small businesses, large corporations, institutions, and governments.

\section{Mission, Strategy, and Values}

'We strive to deliver our financial products and services in the way our customers expect: with exemplary service, maximum convenience and at competitive rates. This is reflected in our mission statement: to set the standard in helping our customers manage their financial future.' (ING Annual Report 2006)

\section{Corporate Values}

ING's management structure follows the principles of transparency, accountability and client focus. Its strategy seeks the following: a clear financial objective; a clear strategy; customer satisfaction; managing costs; managing risks; managing reputation; growth; a performance culture, used to generate business principles which serve to guide employees: committed to our integrity; aim for an above average return; open and clear; promote sustainable development and respect human rights; we respect each other; involved in the communities we operate in (ING Corporate Website).

\section{Corporate Social Responsibility}

Corporate values determine role in society: to maintain stakeholder's confidence by acting with professionalism and integrity. ING has been involved in CSR for a number of years and is structuring is CSR policies. A CSR department was established with CSR parameters defined by the board which see it as a strategic issue based on: entrepreneurship; sustainability as a quality characteristic; success for entrepreneurs. Internally focused on awareness; defining CSR, what is going on in society and how ING can respond? Employees are aware they can contribute to CSR, reinforced through training.

\section{Corporate Social Responsibility and High Potentials CSR Implementation}

All employees learn the business principles through induction and courses on compliance. Groups targeted as able to further CSR receive additional instruction and guidelines to encourage open discussion. High potentials undertook round-table sessions to gain insights as what they want, and think is important, to connect them with CSR. High potentials are considered important for future CSR implementation. Awareness of CSR has been established, ongoing challenge is structurally embed it within development programs.

\section{Competences}

Its leadership profile describes behaviors required in current and future leaders used to measure high potentials, assess general managers, develop the ING Business school curriculum and recruit the right people 1) create shared vision and strategy; 2) drive for result with integrity and compliant behaviour: 3 ) focus on customer; 4) build, engage and empower high performing teams; 5) embrace and drive for change: 6) entrepreneurship (ING Career Website).

\section{CASE 3: DELOITTE NETHERLANDS}

\section{Mission, Strategy, and Values}

'Deliver measurable value to our clients through a global network of diverse professionals who bring unmatched depth and breadth of expertise.' (Deloitte, Annual Report 2005-2006)

Achieved through "Corporate Understandings," which demonstrate strategic direction focus on: leadership; quality; teamwork, and client relationships with associated values and standards of excellence.

\section{Corporate Values}




\section{Running head: THE ROLE OF HIGH POTENTIALS}

Complimentary to strategy, globally shared values were developed that apply to all employees: integrity; outstanding value to markets and clients; commitment to each other; strength from cultural diversity. These form the business code of conduct for all employees focused on public confidence, client and mutual obligations (Deloitte Corporate Website).

\section{Corporate Social Responsibility}

'A form of entrepreneurship based on creating value for our clients, our people and other stakeholders through allocation of human and intellectual capital allowing us to make an actively positive contribution to society and reduce our impact on the environment in a commercially responsible manner.' (Deloitte Stakeholder Report 2005-2006).

In 2006 Deloitte Netherlands' strategic plan placed sustainable growth alongside operational excellence as a top priority. CSR policies are based on nine values and ethical principles: honesty and integrity; professional behaviour; competence: objectivity; confidentiality; fair business practices; responsibility to society; respect and fair treatment: responsible decision-making. CSR strategy focuses on five strategic themes: integrity; employees; member of society; outstanding values for clients; ecological footprint. Deloitte was first of the big four financial service providers in the Netherlands to publish a Corporate Responsibility report and set sustainability goals for 2006 to 2008. Deloitte wants the role of CSR thought leader, to influence society as a whole and be an example for others and apply their knowledge and CSR experience (Deloitte Stakeholder Report 2005 - 2006).

\section{Corporate Social Responsibility and High Potentials CSR Implementation}

CSR implementation involves young people who conducted the zero assessment to define CSR undertaken, because they had various functions, work in a range of departments and locations. This group formed the basis for further CSR implementation and are seen as important because they can encourage CSR adoption.

\section{Competences}

High potential competences required are entrepreneurship, excellent service, commercial skills, leadership effectiveness and effective management, plus to possess professional qualities and social skills. Entrepreneurship is CSR strategy theme which links these.

\section{CASE 4: KPMG NETHERLANDS}

A Dutch company and a member firm of the KPMG network, providing services in Audit, Tax and Advisory. KPMG has an annual turnover of about 634 million Euros, employing 4000 employees in the Netherlands (KPMG Website the Netherlands).

\section{Mission, Strategy, and Values}

'Outstanding professionals working together to deliver value. We offer Audit, Tax and Advisory services. Three complementary areas of knowledge and insight that enable us to meet the needs of our clients. We turn knowledge into value for the benefit of our clients, our people and the capital markets.' (KPMG Annual Report 2005)

Strategy based on four principles: quality and integrity; knowledge and experience; multidisciplinary; the best people.

\section{Corporate Values}

KPMG globally formulated corporate values: act with integrity; work together; respect the individual; seek the facts and provide insight; open and honest in our communication; we are committed to our communities; lead by example. Employees trained to work with these values to guide them in the decisions, considerations and judgments they make that cannot easily classified in training, handbooks or procedures. 


\section{Running head: THE ROLE OF HIGH POTENTIALS}

\section{Corporate Social Responsibility}

'CSR sought through four strategic pillars: 1) Translating and embedding CSR values and principles into business processes and procedures. 2) Decrease effect on the environment, reducing ecological footprint. 3) Invest in Dutch society, focusing on social inclusion, specifically the vulnerable, deprived young, disabled and elderly that are socially isolated. 4) Stakeholder consultation and corporate responsibility reporting. These were created after a broad consultation with internal and external CSR stakeholders which also resulted in the appointment of a CSR director and department.' (KPMG Annual Report 2006).

\section{Corporate Social Responsibility and High Potentials CSR Implementation}

CSR not corporately structurally implemented. Aspects such as a professional code (integrity driven), values and community investment are well developed and embedded. It directors are attentive to CSR, but struggle to show leadership because finding the right themes and to understand the sense of urgency of certain issues is challenging. Organizational culture means CSR is not imposed on individuals who are considered to value traditional work practices.

\section{Competences}

CSR competences are: problem solving; commercial focus; integrity; team work; lead others; build effective relationships; learn from experience; desire to achieve; passionate about client service; proactive. All employees through their annual plan agree how they will fulfill each competency and are measured on this. The plan should include a CSR element as "extra functions" i.e. what they will do in their work for society, this does not form part of their performance evaluation.

\section{CASE 5: IBM NETHERLANDS}

Globally largest information and communication technology company with 300.000 employees in 160 countries and annual revenue of 90 billion dollars. World leader in middleware and second-largest software company overall. Market leader in information management software, application integration, middleware categories, IT services, consulting and server sales (IBM Annual Report 2005).

\section{Mission, Strategy, and Values}

'At IBM, we strive to lead in the invention, development and manufacture of the industry's most advanced information technologies, including computer systems, software, storage systems and microelectronics. We translate these advanced technologies into value for our customers through our professional solutions, services and consulting businesses worldwide.'

IBM seeks to be a partner in its clients' success by enabling their capacity to innovate, so that they may differentiate themselves for competitive advantage in a global economy. IBM views enterprise innovation in terms of products and services, and across all dimensions of its business: processes, model, management systems, culture and role in society.

\section{Corporate Values}

'The IBM values, formed in conjunction with employees, provide the basis for everything employees do: dedication to every client's success; innovation that matters, for our company and world; trust and personal responsibility in all relationships. Values enable organizations to manage themselves in a world where hierarchical controls and rule books no longer work.' (IBM Corporate Website).

\section{Corporate Social Responsibility}

IBM has a long CSR footprint e.g. led on workplace safety before first formal policy was issued in 1967 and established a corporate policy on environmental protection in 1971. CSR strategy: employees; environment; community involvement; supply chain responsibility; governance and compliance (IBM Corporate Responsibility Report 2006). To identify its workforce CSR orientation, IBM launched an intranet site that employees could post examples of social engagement activities. Employee's engagement 
Running head: THE ROLE OF HIGH POTENTIALS

was encouraged through financial donation to the CSR activity triggered when they undertook 40 hours plus on such activities.

Corporate Social Responsibility and High Potentials CSR Implementation

'All new employees including high potentials participate in induction, CSR is part of this. The CSR department does not focus on high potentials, instead focused on convincing current leaders to support CSR. The next step is to work with high potentials as future leaders to gain long term support.'

\section{Competences}

High potential competences realigned to fit new company values: earning peoples trust being trust worthy and acting accordingly are considered as basic behaviors a person should possess. CSR was indirectly involved in the development of the new set of competencies because they reflected IBM's values.

\section{CASE 6: LOGICACMG NETHERLANDS}

Leading international information technology (IT) services-company, providing management and IT consultancy, systems development and integration, outsourced management of targeted business processes across diverse markets. In the Netherlands, focused on consultancy with about 6000 employees (LogicaCMG Website the Netherlands).

\section{Mission, Strategy, and Values}

To help leading organisations worldwide achieve their business objectives through the innovative delivery of information technology and business process solutions'

'Its strategy is to be a provider of international services with local attention: acting as a bridge between business and ICT: and viewing the customer as central, enshrined in the view that when the customer is successful, LogicaCMG and her employees are successful. The company strives for long lasting and intensive customer relationships.'

\section{Corporate Principles}

LogicaCMG, merged with Unilog and WM-data, which all had recognized reputation and ability to successfully deliver to customers due to the quality of their people. Building on the shared legacy of people focused values one set of values and one set of systems and processes were created: openness, communication and involvement; mutual respect, fairness, integrity and meritocracy; professionalism and quality; recruiting the best people and releasing their potential; loyalty; client focus and teamwork. These principles define the way LogicaCMG and its employees do business. (LogicaCMG Annual Report 2006)

\section{Corporate Social Responsibility}

Good standards of corporate responsibility are inherent to its business principles. The company established policies which reflect the company's ethos and attitude towards its employees, customers, other stakeholders and the community in general. CSR is brought into the workplace through partnership with UNICEF to provide education for all children by 2015. The Bloom program involves employees fundraising and free delivery of manpower, ICT knowledge to school related projects in developing countries. Every division has one manager who promotes the program. All employees chose to participate or not in Bloom. The company within the S\&B network shares CSR practice to further its development. It is early on in its CSR orientation but sees CSR as becoming a future strategic focus.

\section{Corporate Social Responsibility and High Potentials CSR implementation}

CSR orientation currently is to people and identified to a limited extent in Human Resource policies because it is only part of the company's agenda. High potentials, just like other employees are confronted with Bloom during a two day introduction. The first day is focused on their business unit. The second day all new employees come together to receive presentations, discussions etc. on social involvement. High potentials are currently not considered important for CSR implementation. 


\section{CASE 7: KPN}

KPN is leading Dutch Telecommunication Company providing telephone, Internet and television services to personal customers through its fixed network in the Netherlands and a range of services, from voice, Internet and data services to full managed outsourced ICT solutions to business customers and mobile services in Western Europe and employees 29.000 (KPN Corporate Website).

\section{Mission, Strategy, and Values \\ 'We are committed to providing a portfolio of modern, high quality telecommunications services to our customers. We want to help our customers to achieve their goals and to enrich their lives, whether for business or pleasure.' (KPN Corporate Website). \\ KPN strategic challenged to develop new services whilst keeping leadership in 'old' markets by: having lowest cost infrastructure; open access infrastructure; providing new for old; new services for consumers: and new services for businesses. KPN believes a society of satisfied customers forms the basis for profitable growth and subsequently shareholder value. Quality and customer satisfaction are realized through motivated employees. Conscious of their responsibilities to the wider community, they contribute through their use of knowledge and technology to all stakeholder well-being, and account to them for their environmental performance (KPN Sustainability Report 2005).}

\section{Corporate Values}

Its Code of Conduct sets out the standards and values of the company and describes how employees are expected to conduct business: personal; trust; simplicity.

\section{Corporate Social Responsibility}

'The products and services of KPN contribute to the improvement of the quality of life. KPN makes it possible to communicate independent of time and place and connects people.'

CSR strategy builds on: 1) Sustainable business, includes ethics, environment and social policy. 2) Social involvement, based on socially responsible initiatives related to products and services e.g. 'My Child Online' foundation which contributes to more responsible use of new media by young people. 3) Personal involvement, how employees and KPN work with society to resolve social issue. All this is moderated by KPN's focus to recover financially after spending considerably in 2001 on acquisitions and mobile internet licenses which almost led to company failure. CSR is important but it a lesser priority than economic well being.

\section{Corporate Social Responsibility and High Potentials CSR Implementation}

All employees including high potentials are confronted with the company code of conduct which has inbuilt CSR elements Although high potentials are not included structurally in CSR it is recognised as future leaders they may become important because they are considered to have different views and values to current leaders.

\section{Competences}

Core competences expected of current and future leaders are: priority; customer; team; influence; result; and change. These competences are not specifically linked to CSR.

\section{CASE 8: SIEMENS NETHERLANDS}

Siemens Netherlands is part of Siemens AG, with turnover of all Siemens companies in the Netherlands around 1.5 million Euros in 2006. With a workforce of 3,188 Siemens Group is one of the leading companies in electrical engineering (Siemens Website the Netherlands). 


\section{Running head: THE ROLE OF HIGH POTENTIALS}

\section{Mission, Strategy, and Values}

'Siemens is a global network of innovation. This worldwide network is formed by people that want to apply their knowledge on electrical engineering and electronics to give their customers a competitive advantage. Siemens employees learn continuously and work closely together with each other and with partners. They are energetic, without loosing the social importance out of sight and are proud to contribute to the success of the organization.' (Siemens Website the Netherlands).

To fulfill its mission its strategy is based on the following: translate urbanization and demographic changes in growing opportunities: market leader position; and Fit4More delivered through performance \& portfolio, continuous adjustment and innovation, operational excellence, the best processes, people excellence, involvement as a basis for success and corporate responsibility, active for people and society (Siemens Website the Netherlands).

\section{Corporate Principles}

Corporate Principles were defined globally and establish standards of integrity for all employees and values for all business activities. Corporate Principles are: strengthen our customers to keep them competitive; push innovation to shape the future; enhance company value to open up new opportunities; empower our people to achieve world-class performance; embrace corporate responsibility to advance society (Siemens Corporate Website).

\section{Corporate Social Responsibility}

Corporate Citizenship is embedded in business activities and is committed to a strategy that generates profit and growth while contributing to the well-being of people and the planet. CSR strategy is focused on people; employees, customers and society, working conditions, labor agreements, sustainable products and services and community investment. For the environment the company mainly complies with the rules and regulations. CSR implementation is considered to be efficient. (Siemens Annual Report 2006).

\section{Corporate Social Responsibility and High Potentials CSR Implementation}

With a clear CSR strategy it seeks to develop current CSR policies further, and identify new projects. High potentials are not targeted to be involved in CSR implementation though they are considered influential. All new employees participate in induction which includes CSR.

\section{Competences}

Competence framework based on: knowledge, experience and behaviour, divided in five themes that represent several competences: 1) Edge: Creativity, entrepreneurship, Autonomy, and Strategic vision and risk management. 2) Energy: Initiative, Willingness to change, Learning capacity, and Professionalism. 3) Energize: Communication skills, Networking, Coaching and Mentoring, and Team player. 4) Execute: Analytical capacity, Decision making ability, and Result and Quality focus. 5) Passion: Customer focus, Integrity, and Siemens Values.

\section{CASE 9: TNT POST}

TNT Post, part of a global provider of mail, express and logistic services. In the Netherlands TNT Post is the market leader in addressed and non-addressed mail. Globally TNT Post has about 80.000 employees of which 40.000 work in the Netherlands. In 2004 the turnover of TNT Post was 3.9 billion Euros (TNT Corporate Website).

\footnotetext{
Mission, Strategy, and Values

'Exceed our customers' expectations in transferring their goods and documents around the world. We deliver value to our clients by providing the most reliable and efficient solutions through delivery networks. We lead the industry by: Instilling pride in our people; creating value for our shareholders; and sharing responsibility for our world. (TNT Social Responsibility Report 2006)'
} 


\section{Running head: THE ROLE OF HIGH POTENTIALS}

\section{Corporate Principles}

Living consistently by TNT Business Principles cements the company's culture. Business operated according to four guiding principles containing seventeen statements: 1) Principles that guide the company; 2) Principles that guide the employees; 3) Principles that guide the business; 4) Principles that guide the relationship with the world (TNT Corporate Website).

\section{Corporate Social Responsibility}

TNT strives to improve its social and environmental impact on communities. To help people realize potential and meet the needs of the current generation without producing a poorer world. The CSR focus is: stakeholders' expectations; core business and accompanying sector-specific issues; competitors' KPI's/target areas, enabling the outside world to compare TNT's performance with that of its competitors; strategy and mission; the Dow Jones Sustainability Group Index.

\section{Corporate Social Responsibility and High Potentials CSR Implementation}

CSR implementation requires employee's awareness which starts with induction program. The goal of this induction is to make employees aware that in their work they should not only focus on profit, but also on people and planet and that CSR has to become part of every project they are involved in. High potentials can take part in the regular CSR activities that are available for everyone. Young TNT, a union of young employees, regularly has CSR initiatives.

\section{Competences}

TNT competence framework does not differentiate between current and future leaders: 1) Key competences-manage with the heart, build on promise, trust others to deliver, action and taking decisions, open for possibilities. 2) Transactional competences-awareness of business and market, customer focused, team work, deliver value, strategic thinking, learning. 3) Basic skills-effective communication, planning, functional knowledge. High potentials should possess or develop these competences and are evaluated on these. TNT wants new employees to have affinity for CSR. No specific competences are directly linked to CSR, performance against CSR criteria not undertaken.

\section{Company Reports}

- ABN AMRO Annual report 2006

- ABN AMRO Sustainability report 2006

- Deloitte Netherlands Annual report 2005 - 2006

- Deloitte Netherlands Stakeholder Report 2005 - 2006

- IBM Annual Report 2005

- IBM Corporate Responsibility Report 2006

- ING Bank Annual Report 2005

- ING Group Corporate Responsibility Report 2006

- KPMG Netherlands Annual report 2005

- $\quad$ KPN Sustainability Report 2006

- LogicaCMG Annual Report 2006

- Siemens Netherlands Annual Report 2006

- $\quad$ TNT Group Social Responsibility report 2006

\section{Websites}

- ABN AMRO Corporate website, www.abnamro.com, last accessed May 15, 2007

- IBM Corporate website www.ibm.com, last accessed May 18, 2007

- ING Career website, www.ing.jobs/careers/, last accessed on May 22, 2007

- ING Group Corporate website, www.ing.com, last accessed May 22, 2007

- KPMG Netherlands website, www.kpmg.nl, last accessed May 18, 2007 


\section{Running head: THE ROLE OF HIGH POTENTIALS}

- KPN Corporate Website www.kpn.com, last accessed May 18, 2007

- LogicaCMG Netherlands website, www.logicacmg.nl, last accessed May 18, 2007

- Samenleving \& Bedrijf Website, www.samen.nl, last accessed March 19, 2007

- $\quad$ TNT Group Corporate website, www.tnt.com, last accessed May 18, 2007 


\section{REFERENCES}

Altman, Y.: 1997. 'The High-Potentials Fast-flying Achiever: Themes from the English Language Literature 1976-1995', Career Development International 2 (7), 324-330.

Atkinson, P.E.: 1990. 'Creating Cultural Change', Management Services 34 (7), 6-10.

Bateson, C.D., Collins, E., and Powell, A.A.: 2006, 'Doing Business After the Fall: The Virtual model of hypocrisy', Journal if Business Ethics 66, 321-335.

Beatty, C.A., and Gordon, J.R.M.: 1991, 'Preaching the Gospel: The Evangelists of NewTechnology', California Management Review 33 (3), 73-94.

Beverland, M.B. and Lindgreen, A.: 2010, 'What Makes a Good Case Study? A Positivist Review of Qualitative Case Research Published in Industrial Marketing Management, 19712006', Industrial Marketing Management 39 (1), 56-63.

Burke, L.A.: 1997, 'Developing High-Potential Employees in the New Business Reality', Business Horizons 40 (2), 18-24.

Carroll, A.B.: 1979, 'A Three-Dimensional Conceptual Model of Corporate Performance', Academy of Management Review 4 (4), 497-505.

Castka, P., Balzarova, M.A., Bamber, C.J., and Sharp, J.M.: 2004, 'How Can SMEs Effectively Implement the CSR Agenda? A UK Case Study Perspective', Corporate Social Responsibility and Environmental Management 11 (3), 140-149.

Cramer, J., Jonker, J., and van der Heijden, A.: 2004, 'Making Sense of Corporate Social Responsibility', Journal of Business Ethics 55 (2), 215-222.

Cramer, J., van der Heijden, A., and Jonker, J.: 2006, 'Corporate Social Responsibility: Making Sense through Thinking and Acting', Business Ethics: A European Review 15 (4), 380-389.

Cox, C. J. and Cooper, C. L.: 1988, High Flyers: An Anatomy of Managerial Success (Basil Blackwell, Oxford).

Derr, C. B., Jones, C., and Toomey, E.L.: 1988, 'Managing High-Potential Employees: Current Practices in Thirty-Three U.S. Corporations', Human Resource Management 27 (3), 273-292.

Doppelt, B.: 2003, Leading Change Toward Sustainability: A Change Management Guide for Business, Government and Civil Society (Greenleaf Publishing, Sheffield).

Dunphy, D.C., Griffiths, A., and Benn, S.: 2003, Organizational Change for Corporate Sustainability: A Guide for Leaders and Change Agents of the Future (Routledge, London).

Elkington, J.: 1997, Cannibals with Forks: The Triple Bottom Line of 21st Century Business (New Society Publishers, Gabriola Island).

Eisenhardt, K.M.: 1989, 'Building Theories from Case Study Research', Academy of Management Review 14 (4), 532-550.

Garriga, E. and Melé, D.: 2004, 'Corporate Social Responsibility Theories: Mapping the Territory', Journal of Business Ethics 53, 51-57.

Gritzmacher, K.J.: 1989, 'Staying Competitive through Strategic Management of Fast-Track Employees', National Productivity Review 8 (4), 421-432.

Hemmingway, C.A.: 2005, 'Personal Values as a Catalyst for Corporate Social Entrepreneurship', Journal of Business Ethics 60, 233-249.

Jick, T.D.: 1979, 'Mixing Qualitative and Quantitative Methods: Triangulation in Action', Administrative Science Quarterly 24 (4), 602-611.

Jonker, J. and de Witte, M.: 2006, Challenge of Organising and Implementing Corporate Social Responsibility (Palgrave, Basingstoke). 
Joyner, B. E. and Payne, D.: 2002, 'Evolution and Implementation: A Study of Values, Business Ethics and Corporate Social Responsibility', Journal of Business Ethics 41(4), 297-311.

Jones, G. and Spooner, K.: 2006, 'Coaching High Achievers', Consulting Psychology Journal: Practice and Research 58 (1), 40-50.

Kellerman, A.: 2006, The S-Factor: A Responsible Guide to Sustainable Leadership (Business Contact, Amsterdam).

Lincoln, Y.S. and Guba, E.: 1985, Naturalistic Inquiry (Sage, Beverly Hills, CA).

Lindgreen, A.: 2008, Managing Market Relationships: Methodological and Empirical Insights (Gower Publishing, Aldershot).

Lindgreen, A., Swaen, V., and Johnston, W.J.: 2009, 'Corporate Social Responsibility: An Empirical Investigation of U.S. Organizations', Journal of Business Ethics 85 (Suppl. 2), 303-323.

Lyon, D.: 2004, 'How Can You Help Organizations Change to Meet the Corporate Responsibility Agenda?' Corporate Responsibility and Environmental Management 11 (3), 133-139.

Maak, T.: 2007, 'Responsible Leadership, Stakeholder Engagement, and the Emergence of Social Capital', Journal of Business Ethics 74, 329-343

Maak, T.: 2008, 'Undivided Corporate Responsibility: Towards a Theory of Corporate Integrity', Journal of Business Ethics 82, 353-368.

Maak, T. and Pless, N. M.: 2006, Responsible Leadership (Routledge, London).

Maignan, I.: 1997, Antecedents and Benefits of Corporate Citizenship: A Comparison of U.S. and French Businesses, unpublished PhD thesis (University of Memphis at Tampa, TN).

Maignan, I., Ferrell, O.C., and Ferrell, L.: 2005, 'A Stakeholder Model for Implementing Social Responsibility in Marketing', European Journal of Marketing 39 (9/10), 956-977.

Maon, F., Lindgreen, A., and Swaen, V.: 2009, 'Designing and Implementing Corporate Social Responsibility: An Integrative Framework Grounded in Theory and Practice', Journal of Business Ethics 87 (Suppl. 1), 71-89.

Maon, F., Lindgreen, A., and Swaen, V.: 2010, 'Organizational Stages and Cultural Phases: A Critical Review and a Consolidative Model of Corporate Social Responsibility Development', International Journal of Management Reviews 12 (1), 20-38.

Matthyssens, P. and Vandenbempt, K.: 2003, 'Cognition-in-Context: Reorienting Research in Business Market Strategy', Journal of Business and Industrial Marketing 18 (6/7), 595-606.

Meyer, J.W., and Rowen, B.: 1977, 'Institutionalized Organizations: Formal Structure as Myth and Ceremony', American Journal of Sociology 38, 340-363

Paine, L.S.: 1994, 'Managing for Organizational Integrity', Harvard Business Review, (MarchApril), 106-117.

Pedersen, E.R. and Neergaard, P.: 2008, 'From Periphery to Centre: How CSR Is Integrated in Mainstream Performance Management Frameworks', Measuring Business Excellence 12 (10), 4-12.

Pepermans, R., Vloeberghs, D., and Perkisas, B.: 2002, 'High Potential Identification Policies: An Empirical Study among Belgian Companies', Journal of Management Development 22 (8), 660-678.

Placet, M., Anderson, R., and Fowler, K.M.: 2005, 'Strategies for Sustainability', Research Technology Management 48 (5), 32-41. 
Porter, M.E. and Kramer, M.R.: 2006, 'Strategy and Society: The Link between Competitive Advantage and Corporate Social Responsibility', Harvard Business Review 84 (12), 78 94.

Randel, A.E.: 2002, 'The Maintenance of an Organization's Socially Responsible Practice: A Cross-Level Framework', Business and Society 41 (1), 61-83

Rausch, E., Sherman, H., and Washbush, J. B.: 2001, 'Defining and Assessing Competencies for Competency-Based, Outcome-Focused Management Development', Journal of Management Development 21 (3), 184-200.

Sociaal Economische Raad (SER): 2000, De Winst van Waarden, Den Haag.

Strauss, A. and Corbin, J.: 1998, Basics of Qualitative Research, 2nd ed. (Sage, Newbury Park, CA).

Thomas, A.S., and Simerly, R.L.: 1994, 'The Chief Executive Officer and Corporate Social Performance: An Interdisciplinary Examination', Journal of Business Ethics 13, 959 - 968.

Van Marrewijk, M. and Werre, M.: 2003, 'Multiple Levels of Corporate Sustainability', Journal of Business Ethics 44, 107 - 119.

Vos, J.F.J.: 2003, 'Corporate Social Responsibility and the Identification of Stakeholders', Corporate Social Responsibility and Environmental Management 10 (3), 141-152.

Waldman, D.A., and Siegal, D.: 2008, 'Defining the Socially Responsible Leader', The Leadership Quarterly 19, 117-131

Werre, M.: 2003. 'Implementing Corporate Social Responsibility: The Chiquita Case', Journal of Business Ethics 44 (2/3), 247-260.

Weaver, G.R Trevino. L.K., and Cochran, P.L.: 1999, 'Integrated and Decoupled Corporate Social Performance: Management Commitments, External Pressures, and Corporate Ethics Practices', Academy of Management Journal 42 (5), 539-552

Yin, R.K.: 1994. Case study research: Design and methods, 2nd ed. (Sage, Thousand Oaks, CA). 
Running head: THE ROLE OF HIGH POTENTIALS

Table 1: CSR Levels of CSR Integration

\begin{tabular}{|c|c|c|c|}
\hline $\begin{array}{l}\text { Dunphy et } \\
\text { al. (2005) }\end{array}$ & $\begin{array}{l}\text { Core } \\
\text { Elements }\end{array}$ & $\begin{array}{l}\text { Van } \\
\text { Marrewijk } \\
\text { and Werre, } \\
(2003)\end{array}$ & $\begin{array}{l}\text { Core } \\
\text { Elements }\end{array}$ \\
\hline Rejection & $\begin{array}{l}\text { Company exists for profit; } \\
\text { employees, society, \& } \\
\text { environment exploited; opposes } \\
\text { CSR rules / regulations }\end{array}$ & & \\
\hline $\begin{array}{l}\text { Non- } \\
\text { responsive }\end{array}$ & $\begin{array}{l}\text { Lacks awareness and ignorant of } \\
\text { CSR, not actively militant } \\
\text { against CSR, profit focused }\end{array}$ & Pre-CSR & $\begin{array}{l}\text { No CSR ambition, may have some } \\
\text { CSR if forced by regulations }\end{array}$ \\
\hline $\begin{array}{c}\text { Complianc } \\
\mathrm{e}\end{array}$ & $\begin{array}{l}\text { Reactive minimal compliance } \\
\text { with rules/ regulations }\end{array}$ & $\begin{array}{l}\text { Compliance- } \\
\text { Driven CSR }\end{array}$ & $\begin{array}{l}\text { CSR as duty/obligation, the correct } \\
\text { behavior. Benefits society/charity to } \\
\text { regulations. }\end{array}$ \\
\hline Efficiency & $\begin{array}{l}\text { See CSR “advantages," change } \\
\text { HRM \& environmental policies } \\
\text { to reduce cost, increase } \\
\text { efficiency }\end{array}$ & $\begin{array}{l}\text { Profit-Driven } \\
\text { CSR }\end{array}$ & $\begin{array}{l}\text { Business case determines CSR } \\
\text { integration \& decision-making } \\
\text { influence: bottom line criteria }\end{array}$ \\
\hline \multirow[b]{2}{*}{$\begin{array}{l}\text { Strategic } \\
\text { proactivity }\end{array}$} & \multirow[t]{2}{*}{$\begin{array}{l}\text { Determines strategy, provides } \\
\text { competitive edge, facilitates } \\
\text { long-term profitability }\end{array}$} & Caring CSR & $\begin{array}{l}\text { Balances social, economic, } \\
\text { environmental, beyond compliance \& } \\
\text { profit maximization, intrinsically } \\
\text { accepts CSR }\end{array}$ \\
\hline & & $\begin{array}{l}\text { Synergistic } \\
\text { CSR }\end{array}$ & $\begin{array}{l}\text { Balances functional solutions to } \\
\text { create value in economic, social \& } \\
\text { environmental dimensions, } \\
\text { facilitating win-win approach with } \\
\text { stakeholders, recognized as the } \\
\text { unavoidable direction for progress }\end{array}$ \\
\hline $\begin{array}{l}\text { The } \\
\text { sustainable } \\
\text { corporation }\end{array}$ & $\begin{array}{l}\text { Internalized idea of a sustainable } \\
\text { world: strong financial returns, } \\
\text { actively \& voluntarily promotes } \\
\text { CSR, global ecological viability, } \\
\text { equitable society \& human } \\
\text { fulfillment }\end{array}$ & Holistic CSR & $\begin{array}{l}\text { CSR fully integrated \& embedded, } \\
\text { contributes to the life of every being } \\
\& \text { entity now \& in the future, all } \\
\text { beings and phenomena mutually } \\
\text { interdependent, sustainability is the } \\
\text { only future, each person \& } \\
\text { organization universally responsible }\end{array}$ \\
\hline
\end{tabular}


Table 2: Stages of CSR Implementation

\begin{tabular}{ll}
\hline Stages of CSR & Explanation \\
Implementation &
\end{tabular}

1) Conduct 'zeroassessment'

2) Develop CSR goals within the organization's mission, vision, and strategy

3) Gain top management support

4) Gain employee support to ensure they own CSR as part of their work life activities

5) Gain support from external stakeholders

6) Prioritize change effort and focus on achieving it

7) Measure progress and fine-tune the process

8) Anchor change

9) Reorder the implementation system
Identify current CSR practice (Cramer et al., 2004; Maignan et al., 2005)

Identify what the organization wants to achieve and how to achieve it (Doppelt, 2003; Lyon, 2004; Werre, 2003).

Senior managers determine strategy and without their support become critical barriers to CSR implementation (Doppelt, 2003; Werre, 2003).

Requires involvement of a cross-section of employees in zero assessment, and effective communication of CSR mission and vision; reinforced though training (Cramer et al., 2004, 2006; Maignan et al., 2005; Werre, 2003)

Groups affected by the organization or which affect the organization, for example, suppliers, distributors, and wider community. Selecting organizations with similar CSR believes consolidates the re-orientation of the business (Castka et al., 2004; Cramer et al., 2004; Maignan et al., 2005)

An acknowledgment of how the change implementation requires the application of finite management and other resources (Doppelt, 2003)

CSR implementation is an iterative approach (Cramer et al., 2004; Porter and Kramer, 2006)

Ensuring the organization's activities results in mutual benefits for it and the society it operates in (Porter and Kramer, 2006; Werre, 2003)

Reflects continuous nature of the process where stages may occur simultaneously, shaped by the situation faced by the organization (Doppelt, 2003) 
Table 3: Differences and Similarities between Regular and Sustainable Competences

\begin{tabular}{|c|c|c|c|c|}
\hline & $\begin{array}{l}\text { Regular } \\
\text { Competences }\end{array}$ & & $\begin{array}{l}\text { Sustainable } \\
\text { Competences }\end{array}$ & \\
\hline \multirow[t]{5}{*}{ Differences } & Leadership & $\begin{array}{l}\text { Cox and Cooper (1988); Derr et al. } \\
\text { (1988); Jones and Spooner (2000); } \\
\text { Pepermans et al. (2003); Rausch et } \\
\text { al. (2001); }\end{array}$ & $\begin{array}{l}\text { Self-management } \\
\text { and self-learning }\end{array}$ & \\
\hline & $\begin{array}{l}\text { Analytic and } \\
\text { problem-solving } \\
\text { skills }\end{array}$ & $\begin{array}{l}\text { Cox and Cooper (1988); } \\
\text { Pepermans et al. (2003); Rausch et } \\
\text { al. (2001) }\end{array}$ & $\begin{array}{l}\text { Being a responsible } \\
\text { person }\end{array}$ & \\
\hline & $\begin{array}{l}\text { Ability to } \\
\text { organize and } \\
\text { manage }\end{array}$ & $\begin{array}{l}\text { Derr et al. (1988); Jones and } \\
\text { Spooner (2000); Rausch et al. } \\
\text { (2001); }\end{array}$ & Trust and integrity & 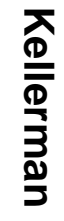 \\
\hline & $\begin{array}{l}\text { Independence and } \\
\text { autonomy }\end{array}$ & $\begin{array}{l}\text { Cox and Cooper (1988); } \\
\text { Gritzmacher (1989); Jones and } \\
\text { Spooner (2000) }\end{array}$ & Coaching & $\begin{array}{l}\text { No } \\
\text { O্] } \\
\end{array}$ \\
\hline & $\begin{array}{l}\text { Improvement and } \\
\text { innovation }\end{array}$ & $\begin{array}{l}\text { Cox and Cooper (1988); } \\
\text { Pepermans et al. (2003); }\end{array}$ & Facilitating change & ฏ \\
\hline \multirow[t]{4}{*}{ Similarities } & $\begin{array}{l}\text { Self confidence } \\
\text { and awareness }\end{array}$ & $\begin{array}{l}\text { Cox and Cooper (1988); } \\
\text { Pepermans et al. (2003); Rausch et } \\
\text { al. (2001); }\end{array}$ & $\begin{array}{l}\text { Self-awareness and } \\
\text { self-motivation }\end{array}$ & $\frac{\mathscr{0}}{\frac{0}{2}}$ \\
\hline & $\begin{array}{l}\text { Communication } \\
\text { and social skills }\end{array}$ & $\begin{array}{l}\text { Derr et al. (1988); Pepermans et al. } \\
\text { (2003); Rausch et al. (2001) }\end{array}$ & $\begin{array}{l}\text { Communicate } \\
\text { vision and mission }\end{array}$ & $\begin{array}{l}\text { S } \\
\text { ș } \\
\text { No }\end{array}$ \\
\hline & $\begin{array}{l}\text { Creativity and } \\
\text { flexibility }\end{array}$ & $\begin{array}{l}\text { Gritzmacher (1989); Pepermans et } \\
\text { al. (2003) }\end{array}$ & Creativity & 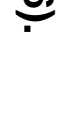 \\
\hline & $\begin{array}{l}\text { Team work and } \\
\text { team building, as } \\
\text { well as social } \\
\text { awareness }\end{array}$ & $\begin{array}{l}\text { Cox and Cooper (1988); } \\
\text { Pepermans et al. (2003); } \\
\text { Gritzmacher (1989) Rausch et al. } \\
(2001)\end{array}$ & $\begin{array}{l}\text { Relationship } \\
\text { management and } \\
\text { building and } \\
\text { teamwork }\end{array}$ & \\
\hline
\end{tabular}


Running head: THE ROLE OF HIGH POTENTIALS

Table 4: Regular and CSR High Potential Competencies

\section{Competence}

\section{Number of Organizations Citing}

Competency

\begin{tabular}{ll}
\hline Create vision and strategy & $\mathbf{3}$ \\
Integrity, compliance, trust, and honesty & $\mathbf{8}$ \\
Focus on customer / excellent service & $\mathbf{7}$ \\
Leadership & $\mathbf{6}$ \\
Facilitating change & $\mathbf{2}$ \\
Entrepreneurship & $\mathbf{3}$ \\
Respect & $\mathbf{3}$ \\
Professionalism & $\mathbf{3}$ \\
Courage & $\mathbf{1}$ \\
Risk taking and management & $\mathbf{2}$ \\
Commercial drive & $\mathbf{4}$ \\
Result focus & $\mathbf{3}$ \\
Ambition & $\mathbf{3}$ \\
Effective management & $\mathbf{2}$ \\
Proactive & $\mathbf{2}$ \\
Problem solving & $\mathbf{1}$ \\
Learning capacity & $\mathbf{3}$ \\
Innovation and creativity & $\mathbf{2}$ \\
Autonomy & $\mathbf{1}$ \\
Initiative & $\mathbf{1}$ \\
Coaching & $\mathbf{1}$ \\
Openness or social awareness & $\mathbf{3}$ \\
Responsibility in relationships and teamwork & $\mathbf{7}$ \\
Planning & $\mathbf{1}$ \\
Communication & $\mathbf{2}$ \\
Self awareness & $\mathbf{1}$ \\
Self management & $\mathbf{1}$ \\
Social skills & 1 \\
\hline Notes: Shaded rows are those the & $\mathbf{1}$ \\
\hline
\end{tabular}

Notes: Shaded rows are those the organizations identified as related to CSR. 
Table 5: Identified Stages of CSR Implementation Used by Sampled Organizations

\section{Stages of CSR Implementation Notes}

1) Conduct zero-assessment

2) Develop CSR goals in organization's mission, vision, and strategy

3) Gain top management support

4) Gain employee support to ensure they own CSR as part of their work life activities

5) Gain support from external stakeholders

6) Prioritize change effort and focus on achieving it
One organization used a team of young starters to identify the level of CSR activity and then act as CSR ambassadors to strengthen CSR engagement

All nine organizations have a CSR strategy through which they define their activities (see the Appendix)

Two organizations had proactive senior management support; the remaining were seeking to strengthen it

All organizations were active in achieving employee support through a range of initiatives. The extent to which it had become universally accepted was difficult to gauge, and the task was considered relatively large, requiring time

All organizations sought stakeholder support, three focused especially on the issues of stakeholders and stakeholder management, and one organized an extensive stakeholder dialogue

A range of CSR-related areas were covered, linked to each organization's core business processes. Three focused on the people part of CSR, and three on community investment projects. One had yet to define the themes 